\title{
Increased responsiveness to intravenous lipopolysaccharide challenge in steers grazing endophyte-infected tall fescue compared with steers grazing endophyte-free tall fescue
}

\author{
N M Filipov, F N Thompson, J A Stuedemann ${ }^{1}$, T H Elsasser ${ }^{2}$, \\ S Kahl ${ }^{2}$, R P Sharma, C R Young ${ }^{3}$, L H Stanker ${ }^{3}$ and C K Smith \\ College of Veterinary Medicine, University of Georgia, Athens, Georgia, USA \\ ${ }^{1}$ USDA/ARS, J Phil Campbell Sr, Natural Resource Conservation Center, Watkinsville, Georgia, USA \\ ${ }^{2}$ USDA/ARS, Growth Biology Laboratory, Beltsville, Maryland, USA \\ ${ }^{3}$ USDA/ARS, Food Animal Protection Research Laboratory, College Station, Texas, USA \\ (Requests for offprints should be addressed to F N Thompson, Department of Physiology and Pharmacology, College of Veterinary Medicine, \\ University of Georgia, Athens, Georgia 30602, USA; Email: thompson@calc.vet.uga.edu) \\ (N M Filipov is now at Wadsworth Center, New York State Department of Health, PO Box 509 Empire State Plaza, Albany, New York 12201, USA)
}

\begin{abstract}
Fescue toxicosis in cattle occurs as a result of consumption of ergot alkaloids in endophyte-infected (E+, Neotyphodium coenophialum) tall fescue (Festuca arundinacea). The condition is characterized by pyrexia, decreased weight gains, rough hair coats, and decreased calving rates. The objective of this experiment was to investigate whether steers grazing $\mathrm{E}+$ fescue have altered host response to lipopolysaccharide (endotoxin, LPS) challenge compared with steers grazing endophyte-free $(\mathrm{E}-)$ fescue. Angus steers $(n=8)$ had continuously grazed either $\mathrm{E}+(n=4)$ or $\mathrm{E}-(n=4)$ tall fescue grass for 8 months prior to the experiment. The $\mathrm{E}+$ steers had lower body weight, depressed average daily gain, and decreased basal serum prolactin compared with the $\mathrm{E}-$ steers prior to LPS administration. Each steer received a single bolus i.v. injection of LPS $(0 \cdot 2 \mu \mathrm{g} / \mathrm{kg}$ body weight; Escherichia coli;
\end{abstract}

026:B6) dissolved in sterile saline, and blood was serially collected every $30 \mathrm{~min}$ for $4 \mathrm{~h}$ and at $24 \mathrm{~h}$ post LPS administration.

LPS increased serum tumor necrosis factor- $\alpha$ (TNF- $\alpha$ ), cortisol, and haptoglobin but decreased plasma glucose and IGF-I. Importantly, however, TNF- $\alpha$, cortisol, and IGF-I responses to LPS were greater in $\mathrm{E}+$ compared with $\mathrm{E}-$ steers. These results indicated that animals grazing $\mathrm{E}+$ fescue had altered integrated metabolic host response compared with animals grazing $\mathrm{E}-$ fescue. Potentially, combined exposure to E+ fescue and a bacterial LPS could have greater deleterious effects on the animal compared with exposure to only one of the two and would likely lead to increased catabolism.

Journal of Endocrinology (1999) 163, 213-220

\section{Introduction}

Consumption of endophyte-infected (E+, Neotyphodium coenophialum; Glenn et al. 1996) tall fescue (Festuca arundinacea Schreb) is associated with fescue toxicosis in cattle (Thompson \& Stuedemann 1993, Oliver 1997). Numerous ergot alkaloids found in $\mathrm{E}+$ fescue are implicated as toxic agents (Porter 1995). Rough hair coats, increased body temperature, decreased intake, weight gains and reproductive efficiency, and alteration in secretion of various pituitary hormones are associated with ingestion of E + fescue (Thompson \& Stuedemann 1993). Among a variety of clinical chemistry changes such as depressed serum alkaline phosphatase (Oliver 1997) associated with fescue toxicosis, circulating prolactin (PRL) is generally decreased (Lipham et al. 1989, Aldrich et al. 1993).
An emerging body of literature indicates that an immune challenge leads to metabolic and endocrine shifts, which ultimately lead to decreased growth (Elsasser et al. 1995b, Spurlock 1997). An immune challenge may be bacterial or viral infection, acute stress, or other nonpathogenic challenge. Typically, an immune challenge results in an increase of one or, more often, all of the proinflammatory cytokines (interleukin-1 (IL-1), IL-6, and tumor necrosis factor- $\alpha$ (TNF- $\alpha)$ ). Once increased, these cytokines may invoke other immune modulators such as cortisol. The effects of TNF- $\alpha$, for example, are consistent with the pathophysiology of fescue toxicosis (Thompson \& Stuedemann 1993). Lipopolysaccharide (endotoxin, LPS) is a potent inducer of the proinflammatory cytokines, and these bring about the acute phase response. For example, marked increases of plasma TNF- $\alpha$ 
and cortisol were observed following LPS administration in cattle (Elsasser et el. 1994). Similarly, Webel et al. (1997) demonstrated in swine that intraperitoneal injection of LPS leads to increase of TNF- $\alpha$, IL-6, and cortisol, followed by an increase in urea nitrogen, an indicator of induced protein catabolism. In cattle, haptoglobin $(\mathrm{Hp})$ is one of the major acute phase proteins synthesized in the liver during inflammation (Godson et al. 1995, Young et al. 1996), and there have not been reports as to whether $\mathrm{Hp}$ is affected in fescue toxicosis.

Purdy et al. (1989) reported that steers grazing E+ fescue pastures that are moved to feedlots have increased morbidity and mortality and a decreased resistance to transportation stress. Moreover, there are speculations that consumption of $\mathrm{E}+$ fescue results in a decreased pathogen resistance. Therefore, measurement of the host response to an inflammatory challenge was regarded as being potentially helpful to further the understanding of the fescue toxicosis condition.

Thus, the objective of this study was to determine if consumption of $\mathrm{E}+$ fescue alters the host response to LPS challenge. We hypothesized that grazing E+ fescue forage would result in greater host response to LPS challenge compared with consumption of endophyte-free $(\mathrm{E}-)$ fescue forage and that may result in increased catabolism.

\section{Materials and Methods}

Animals

Angus steers $(n=8)$ continuously grazed either $\mathrm{E}+(n=4)$ or $\mathrm{E}-(n=4)$ tall fescue grass pastures from 22 April to 9 December 1997 (USDA/ARS, Natural Resource Conservation Center, Watkinsville, GA, USA). Before random assignment to $\mathrm{E}+/ \mathrm{E}$ - pastures, animals were weighed (16 h off-water weight) and blood was collected for serum PRL determination. Steer weight before beginning of grazing was $213.5 \pm 3.3 \mathrm{~kg}$ (means \pm s.D.) and serum PRL was $132 \cdot 4 \pm 41 \cdot 27 \mathrm{ng} / \mathrm{ml}$ (means \pm s.E.M.). Neither body weight nor serum PRL were different between $\mathrm{E}+$ and $\mathrm{E}-$ steers. The $\mathrm{E}+/ \mathrm{E}-$ pastures were tested for the endophyte using tissue immunoblot kits (Agrinostics, Watkinsville, GA, USA). E+ pastures were $>90 \%$ infected, whereas the $\mathrm{E}-$ pastures tested $0 \%$ endophyte infection. Additionally, total ergot alkaloid concentration was monitored throughout the grazing season using enzyme-linked immunosorbent assay (ELISA) according to Hill \& Agee (1994). Ergot alkaloid concentration varied during the grazing season from 1 to $3.3 \mathrm{mg} / \mathrm{kg}$ for $\mathrm{E}+$ fescue whereas it was always less than $0.03 \mathrm{mg} / \mathrm{kg}$ for $\mathrm{E}-$ fescue grass. The day before the experiment, E+ steer weights $(358.4 \pm 11.8 \mathrm{~kg}$, mean \pm S.D. $)$ were decreased $(P<0 \cdot 01)$ compared with $E-$ steers $(393 \pm 19 \cdot 3 \mathrm{~kg})$. Similarly, average daily gain (22 April to 9 December 1997) was depressed $(P<0 \cdot 02)$ in the $\mathrm{E}+$ group $(0.63 \pm 0.06 \mathrm{~kg}$, mean \pm s.D. $)$ compared with $\mathrm{E}-(0.77 \pm 0.08 \mathrm{~kg})$. After weighing, an indwelling cannula (Tygon; $1.02 \mathrm{~mm}$ internal diameter, $1.78 \mathrm{~mm}$ outside diameter) was surgically placed into each steer's jugular vein for administration of LPS and for blood collection according to Hill et al. (1994). Endotoxin challenge was performed on the following day. Animals were tethered in individual stalls and provided with water ad libitum. Ambient temperature on the day of the endotoxin challenge (10 December 1997) averaged $11{ }^{\circ} \mathrm{C}$.

Treatment and data collection Prior to LPS administration, two sham blood samples $(10 \mathrm{ml} / \mathrm{sample})$ were collected and discarded to accustom animals to blood collection. Blood samples were then collected into sterile tubes (Vacutainer; Becton Dickinson, Rutherford, NJ, USA) at times -30 and 0 min for determination of basal levels. At time 0 , each steer received a single i.v. bolus of LPS $(0 \cdot 2 \mu \mathrm{g} / \mathrm{kg}$ body weight; Escherichia coli; 026:B6; Sigma, St Louis, MO, USA) dissolved in sterile saline $(5 \mathrm{ml})$. Following LPS administration, blood samples were collected at 30-min intervals for $4 \mathrm{~h}$, and steers were not fed. All animals were then returned to pastures and brought back the next morning to the sampling stalls for an additional blood collection at $24 \mathrm{~h}$ post LPS. After each blood collection and LPS administration, sterile 3.5\% sodium citrate was placed in the cannulas to maintain patency and prevent blood clotting. Serum was then harvested, aliquotted, and stored at $-70{ }^{\circ} \mathrm{C}$ until assayed for the compounds of interest.

\section{Assay procedures}

Prolactin Serum concentrations of PRL were determined by RIA procedures as in Mizinga et al. (1992) with reagents supplied by the USDA Hormone Distribution Program (Beltsville, MD, USA). The intra- and interassay coefficients of variation (C.V.) were $3.7 \%$ and $7 \cdot 3 \%$ respectively.

Growth hormone Serum concentrations of growth hormone $(\mathrm{GH})$ were measured by RIA as described previously (Elsasser et al. 1986) using reagents and protocol supplied by the USDA Hormone Distribution Program and the National Pituitary Agency, Bethesda, MD, USA. All samples were assayed together with an intra-assay C.V. of $8.5 \%$.

Cortisol Serum cortisol was determined with a commercially available solid-phase RIA kit (Diagnostic Products Corp., Los Angeles, CA, USA) which has a $2 \mathrm{ng} / \mathrm{ml}$ limit of detection. All samples were assayed together with an intra-assay C.V. of $7 \cdot 9 \%$.

Tumor necrosis factor- $\alpha$ Serum immunoreactive TNF- $\alpha$ was measured by a specific RIA for the bovine as 
described by Kenison et al. (1990). All samples were assayed together with an intra-assay C.V. of $9 \cdot 2 \%$.

Serum urea nitrogen Serum urea nitrogen (SUN) was determined using a commercially available kit based on colorimetric endpoint ultraviolet method (Sigma Diagnostics, St Louis, MO, USA).

Insulin-like growth factor-I Insulin-like growth factor-I (IGF-I) was determined by RIA according to Elsasser et al. (1988). All samples were assayed together with an intra-assay C.V. of $8 \cdot 1 \%$.

Haptoglobin Serum concentration of $\mathrm{Hp}$ was determined by an ELISA according to Young et al. (1995) using plates coated with hemoglobin for capture and antihaptoglobin monoclonal antibody for detection of serum Hp.

\section{Statistical analysis}

Analysis was performed using the Statistix software (Statistix Analytical Software, Tallahassee, FL, USA). All data were subjected to analysis of variance (ANOVA) with the following terms in the statistical model: steer, treatment, time, treatment $\times$ time. If significant effect of time within treatment, or treatment $\times$ time occurred $(P<0 \cdot 05)$ means were separated by Fisher's PLSD post hoc test. Response over time areas under the curve were calculated for TNF- $\alpha$ and SUN responses. Calculations were performed using trapezoidal summation of individual areas according to Elsasser et al. (1996).

\section{Results}

Steers grazing E + fescue exhibited signs of fescue toxicosis (Thompson \& Stuedemann 1993, Oliver 1997) including rough hair coats and decreased body weight gains. Basal circulating PRL was also reduced $(P<0.001)$ in the $\mathrm{E}+$ group $(0.36 \pm 0.02$ vs $14.11 \pm 3.33 \mathrm{ng} / \mathrm{ml}$, mean \pm s.E.M. for $\mathrm{E}+\mathrm{vs} \mathrm{E}$ - respectively) prior to LPS administration. While LPS administration itself resulted in insignificant changes of circulating PRL in both the $\mathrm{E}+$ and $\mathrm{E}-$ groups, serum PRL in the $\mathrm{E}+$ group remained reduced compared with $\mathrm{E}-$ during the entire LPS challenge (data not shown).

Prior to LPS challenge, serum TNF- $\alpha$ concentrations were low and not different between groups. However, serum TNF- $\alpha$ rapidly increased in both $\mathrm{E}+$ and $\mathrm{E}-$ groups following LPS (Fig. 1a). Across groups, comparison of the increases in TNF- $\alpha$ revealed that the TNF- $\alpha$ response was of greater magnitude and duration in the $\mathrm{E}+$ group $(P<0 \cdot 001)$. Consequently, the integrated area under the curve (AUC) TNF- $\alpha$ response in the $\mathrm{E}+$ group was greater $(P<0 \cdot 05)$ compared with $\mathrm{E}-($ Fig. $1 b)$. In both
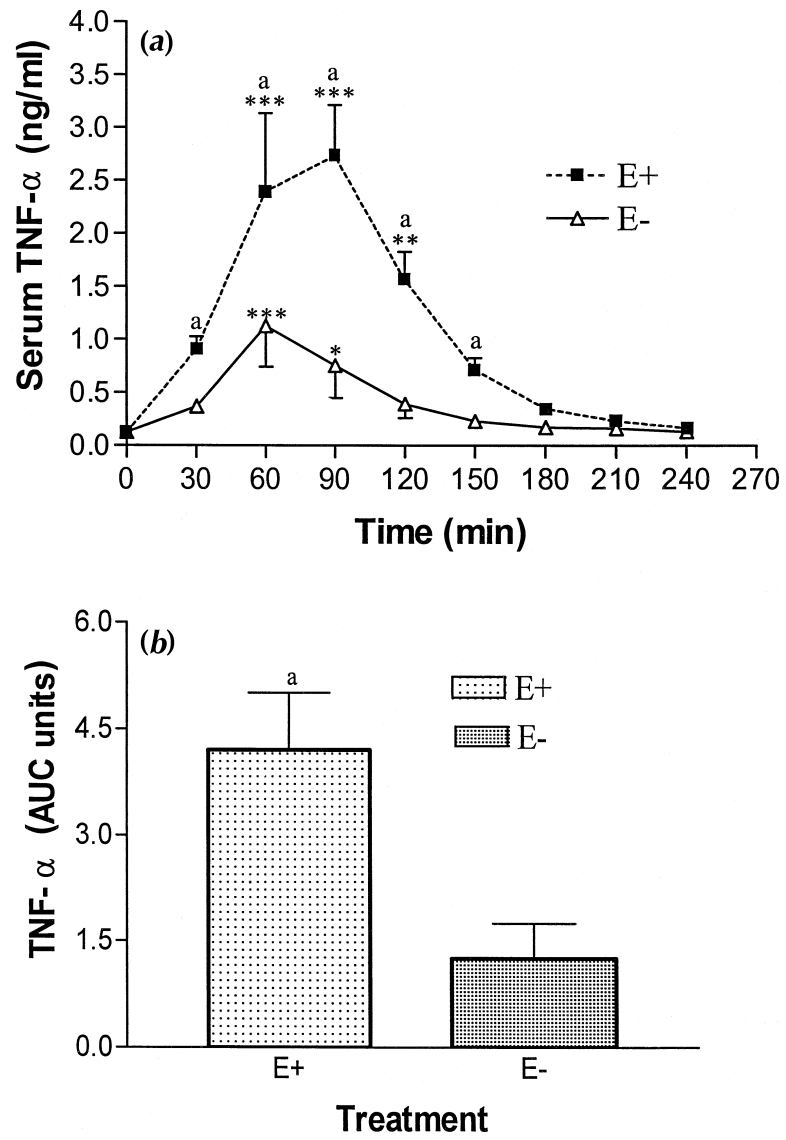

Figure 1 (a) Serum TNF- $\alpha$ (mean \pm S.E.M.) concentration and (b) area under the TNF- $\alpha$ concentration time-response curve in steers ( $n=4$ /group) grazing $\mathrm{E}+$ or $\mathrm{E}-$ tall fescue challenged with $0 \cdot 2 \mu \mathrm{g} / \mathrm{kg}$ body weight LPS i.v. bolus at time $0 .{ }^{*} P<0 \cdot 05,{ }^{*} P<0 \cdot 01$, $* * * P<0.001$ vs 0 within the same treatment (a). ${ }^{a}$ Indicates between treatment differences at specific time-points $(P<0.001$ in $(a))$, or AUC differences $(P<0 \cdot 05$ in $(b))$.

$\mathrm{E}+$ and $\mathrm{E}-$ groups, serum TNF- $\alpha$ returned to baseline by $4 \mathrm{~h}$ and was not different thereafter (values at $24 \mathrm{~h}$ not shown).

Serum Hp concentrations were not different between groups prior to LPS (Table 1). Following LPS challenge, $\mathrm{Hp}$ gradually increased in both groups and was greater $(P<0 \cdot 01)$ within both treatments at $24 \mathrm{~h}$.

Serum cortisol was not different prior to LPS but rapidly increased following LPS in both groups $(P<0 \cdot 0001)$, and remained elevated for $240 \mathrm{~min}$ (Fig. 2). Serum cortisol was greater $(P<0.05)$ in $\mathrm{E}+$ compared with $\mathrm{E}-$ at $180 \mathrm{~min}$ and tended to be greater at $210(P=0.09)$ and 240 $(P=0.07) \mathrm{min}$ respectively. At $240 \mathrm{~min}$ post LPS treatment, $\mathrm{E}-$ serum cortisol was not different from pre-LPS values, whereas $\mathrm{E}+$ serum cortisol remained elevated. Therefore, serum cortisol response to LPS in the E + group was greater compared with the $\mathrm{E}-$ group. 
Table 1 Serum Hp concentrations (mean \pm S.E.M., mg/dl), and $\mathrm{Hp} \mathrm{AUC} \mathrm{in} \mathrm{steers}$ $(n=4$ /group) grazing $E+$ or $E-$ tall fescue challenged with $0 \cdot 2 \mu \mathrm{g} / \mathrm{kg}$ body weight LPS i.v. bolus at time 0

\begin{tabular}{|c|c|c|c|c|}
\hline & \multicolumn{4}{|l|}{ Time } \\
\hline & $0^{\mathrm{a}}$ & $30 \mathrm{~min}-4 \mathrm{~h}$ & $24 \mathrm{~h}$ & AUC \\
\hline \multicolumn{5}{|c|}{ Treatments } \\
\hline$E+$ & $<1 \cdot 00$ & $1 \cdot 25 \pm 0.067$ & $1 \cdot 61 \pm 0 \cdot 21^{* * *}$ & $9 \cdot 18 \pm 2 \cdot 64$ \\
\hline$E-$ & $<1.00$ & $1 \cdot 17 \pm 0.065$ & $1 \cdot 31 \pm 0.067^{* *}$ & $7 \cdot 01 \pm 1 \cdot 44$ \\
\hline
\end{tabular}

${ }^{* *} P<0 \cdot 01,{ }^{* * *} P<0 \cdot 001$ vs time 0 within treatment.

aTime 0 is the average of $-30 \mathrm{~min}$ and 0 bleeding times. For statistical purposes samples with $\mathrm{Hp}$ values of $<1 \mathrm{mg} / \mathrm{dl}$ (below assay sensitivity) were assigned a value of $1 \mathrm{mg} / \mathrm{dl}$.

There were no treatment differences in serum GH prior to LPS and the GH response to LPS was similar in both groups (Fig. 3). Circulating GH increased $(P<0 \cdot 05)$ at $60 \mathrm{~min}$ in both groups compared with pretreatment values and similarly $\mathrm{GH}$ was increased in $\mathrm{E}+$ at $120 \mathrm{~min}$ $(P<0 \cdot 01)$. Serum GH was again increased $(P<0 \cdot 01)$ in both groups at $24 \mathrm{~h}$ compared with respective pretreatment $\mathrm{GH}$ concentrations.

Serum IGF-I concentrations in the $\mathrm{E}+$ group were decreased $(P<0 \cdot 05)$ compared with $\mathrm{E}-$ both before and after LPS (Fig. 4). Following LPS, serum IGF-I decreased in both groups. The magnitude of this decrease was $22 \%$ and $18 \%$ for $\mathrm{E}-$ and $\mathrm{E}+$ respectively at $24 \mathrm{~h}$. Within the $\mathrm{E}-$ treatment, the decrement in serum IGF-I with time (0 vs $24 \mathrm{~h})$ was significant $(P<0 \cdot 05)$.

Serum glucose concentration was decreased $(P<0 \cdot 05)$ in the $\mathrm{E}+$ compared with $\mathrm{E}-$ group prior to LPS challenge (Fig. 5). A hypoglycemic response to LPS was apparent in both groups by the third hour; however, across treatments

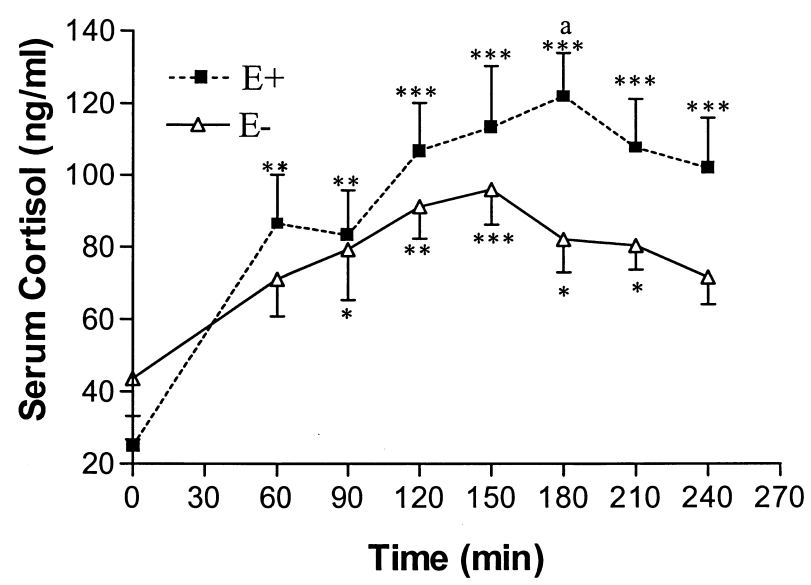

Figure 2 Serum cortisol concentration (mean \pm S.E.M.) in steers ( $n=4$ /group) grazing $\mathrm{E}+$ or $\mathrm{E}-$ tall fescue challenged with $0 \cdot 2 \mu \mathrm{g} / \mathrm{kg}$ body weight LPS i.v. bolus at time 0 . ${ }^{\mathrm{a}}$ Cortisol values were greater in $\mathrm{E}+$ compared with $\mathrm{E}-(P<0 \cdot 05)$ at $180 \mathrm{~min}$ and tended to be greater $(P=0 \cdot 09, P=0 \cdot 07)$ at times 210 and $240 \mathrm{~min}$ after LPS treatment respectively. ${ }^{\star} P<0 \cdot 05,{ }^{* *} P<0 \cdot 01,{ }^{* * *} P<0 \cdot 001$ vs time 0 within treatment. serum glucose was lowered $(P<0 \cdot 05)$ in the $\mathrm{E}+$ group at 180 and $210 \mathrm{~min}$. The maximal decrease in serum glucose was $29 \%$ and $28 \%$ for the $\mathrm{E}+$ and $\mathrm{E}-$ groups respectively. At $24 \mathrm{~h}$ post LPS, there were no treatment differences $(78.1 \pm 2.7$ and $90 \pm 4.9 \mathrm{mg} / \mathrm{dl}$, means \pm S.E.M. for $\mathrm{E}+$ and $\mathrm{E}-$ respectively).

Mean SUN values were $13.74 \pm 0.32$ and $13.95 \pm$ $0.38 \mathrm{mg} / \mathrm{dl}$ (means \pm s.E.M.) for $\mathrm{E}+$ and $\mathrm{E}-$ respectively, and were not different. However, LPS challenge resulted in SUN AUC $(0-24 \mathrm{~h})$ response of $23 \cdot 4 \pm 3 \cdot 8$ AUC units (mean \pm s.E.M.) that was upward (net increase) in the $\mathrm{E}+$ group. On the other hand, the $\mathrm{E}-$ the $\mathrm{SUN}$ response (47.4 $\pm 12 \cdot 3$ AUC units) was downward (net decrease) and different $(P<0 \cdot 01)$ from $\mathrm{E}+\mathrm{SUN}$ AUC response to LPS.

\section{Discussion}

The decreased weight gain, signs the animals exhibited, and the decreased serum PRL in the E + group indicated

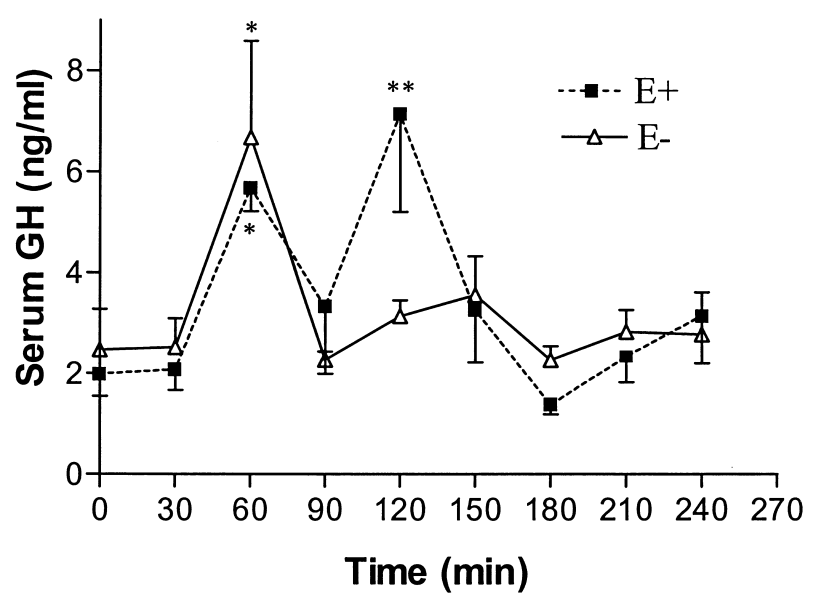

Figure 3 Serum GH concentration (mean \pm S.E.M.) in steers ( $n=4$ /group) grazing $\mathrm{E}+$ or $\mathrm{E}-$ tall fescue challenged with $0 \cdot 2 \mu \mathrm{g} / \mathrm{kg}$ body weight LPS i.v. bolus at time 0 . There was no treatment or treatment $\times$ time effect $(P>0 \cdot 05)$. At $24 \mathrm{~h}$ (data not shown) $\mathrm{GH}$ was increased compared with pretreatment values in both $\mathrm{E}+$ and $\mathrm{E}-.{ }^{*} P<0 \cdot 05,{ }^{*} P<00 \cdot 01$ vs time 0 within treatment. 


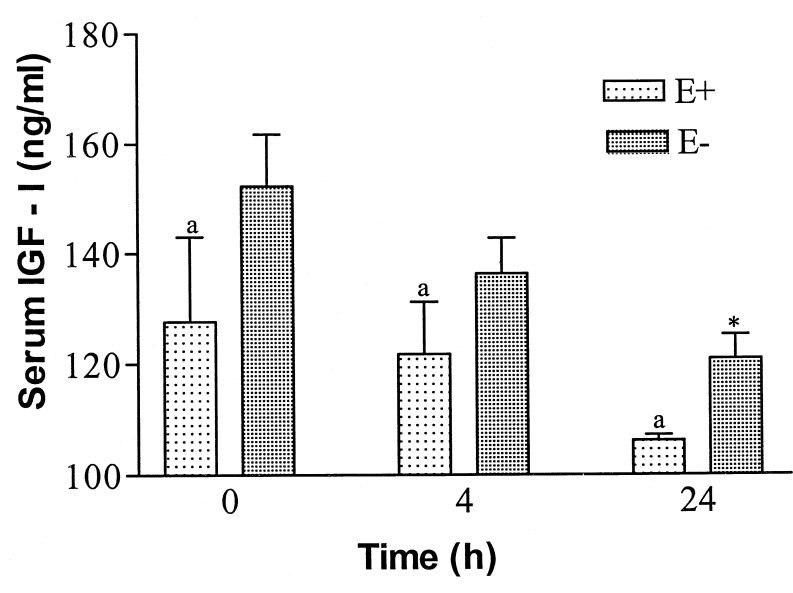

Figure 4 Concentration of IGF-I (mean \pm S.E.M.) in steers ( $n=4$ /group) grazing $\mathrm{E}+$ or $\mathrm{E}-$ tall fescue challenged with $0 \cdot 2 \mu \mathrm{g} / \mathrm{kg}$ body weight LPS i.v. bolus at time 0 . ${ }^{\mathrm{a}}$ IGF-I values were decreased $(P<0.05)$ in $\mathrm{E}+$ compared with $\mathrm{E}-$ for the entire period. ${ }^{*} P<0.05$ vs time 0 within treatment.

that this group was affected by the endophyte-infected forage. It is surmised that the ergot alkaloids present in the $\mathrm{E}+$ forage were the reason for this difference. The decrease in PRL is a widely used marker for ergot alkaloid effect (Thompson \& Stuedemann 1993) and it has been frequently observed in cattle following consumption of $\mathrm{E}+$ fescue (Thompson et al. 1987, Lipham et al. 1989, Aldrich et al. 1993). The decreased circulating PRL in cattle ingesting $\mathrm{E}+$ fescue forage is attributed to a dopaminergic activity of ergot alkaloids in $\mathrm{E}+$ fescue (Thompson et al. 1987).

The dose of LPS $(0 \cdot 2 \mu \mathrm{g} / \mathrm{kg})$ that was used here is the lowest reported in cattle that would result in a host

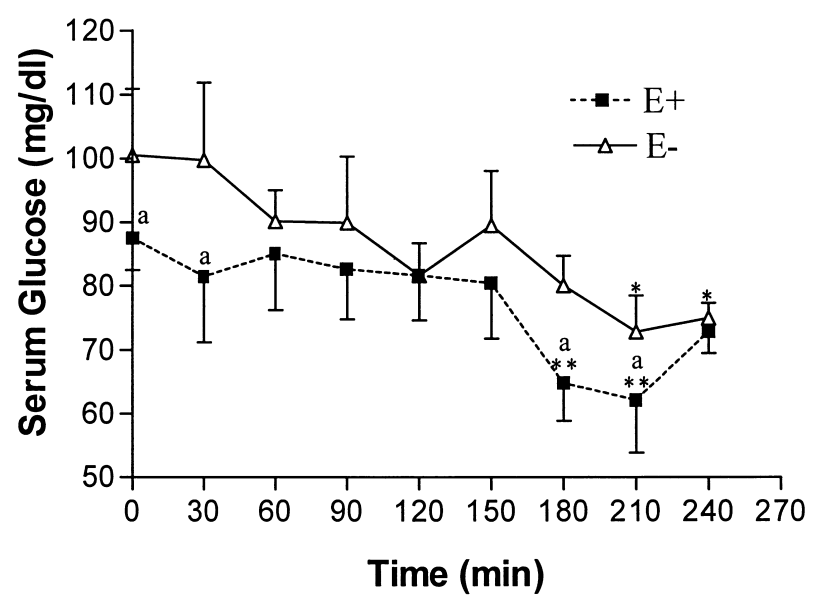

Figure 5 Serum glucose concentration (mean \pm S.E.M.) in steers ( $n=4$ /group) grazing $\mathrm{E}+$ or $\mathrm{E}-$ tall fescue challenged with $0 \cdot 2 \mu \mathrm{g} / \mathrm{kg}$ body weight LPS i.v. bolus at time 0 . ${ }^{\mathrm{a}}$ Glucose values for $\mathrm{E}+$ were lower $(P<0 \cdot 05)$ compared with $\mathrm{E}-$ before LPS treatment and for most of the 240-min sampling period, but not at $24 \mathrm{~h}$ (data not shown). ${ }^{*} P<0 \cdot 05,{ }^{*} P<0 \cdot 01$ vs time 0 within treatment. response (Elsasser et al. 1996), but would not be injurious. No animals appeared to be affected beyond slight coughing and perhaps lethargy and both the coughing and the lethargy were not apparent after the first four hours of the experiment.

The magnitude and duration of the TNF- $\alpha$ increase seen following LPS challenge was similar to cattle (Kahl et al. 1997) and sheep (Coleman et al. 1993). The augmented TNF- $\alpha$ response in the $\mathrm{E}+$ steers may have been an effect of decreased feed intake, the effects of the ergot alkaloids in the $\mathrm{E}+$ forage, or both. Intake is decreased in cattle grazing $\mathrm{E}+$ fescue (Thompson \& Studemann 1993). In this regard, chronic decrease in intake in humans was reflected by enhanced TNF- $\alpha$ production by monocytes stimulated in vitro (Vaisman et al. 1989). Alternatively, ergot alkaloids in $\mathrm{E}+$ forage can themselves induce a variety of host responses in cattle, including increased levels of thromboxane $\mathrm{B}_{2}$, von Willibrand factor, and angiotensin-converting enzyme (Oliver 1997). The significance of this difference would appear to be that animals grazing $\mathrm{E}+$ fescue would have greater muscle catabolism in response to an inflammatory challenge because increased circulating TNF- $\alpha$ is associated with increased muscle protein catabolism (Zamir $e t$ al. 1992).

The increased $\mathrm{Hp}$ in both groups in response to LPS is indicative of an inflammatory response. $\mathrm{Hp}$ is one of the major acute phase proteins in cattle (Godson et al. 1995, Young et al. 1996). The sampling duration here following LPS may not have been sufficiently long to observe an effect across treatment groups. For example, cattle challenged with the proinflammatory cytokine IL-1 (Godson et al. 1995) had elevated serum Hp within $24 \mathrm{~h}$, and it remained elevated for $72 \mathrm{~h}$. Moreover, Cheryk et al. (1998) reported increased $\mathrm{Hp}$ values in cattle within $24 \mathrm{~h}$, and peak values $72 \mathrm{~h}$ post bacterial challenge with Pasteurella haemolytica A1. Nevertheless, the lack of initial difference between $\mathrm{E}+$ and $\mathrm{E}-$ indicates acute phase protein synthesis, such as $\mathrm{Hp}$ in the liver, is not likely to be stimulated by a chronic exposure to ergot alkaloids.

Previously, plasma cortisol in steers was not affected by consumption of $\mathrm{E}+$ fescue (Aldrich et al. 1993). Acute administration of ergotamine, however, promptly increased plasma cortisol levels in cattle (Browning et al. 1998). The increased cortisol response to LPS in the E+ steers observed here indicates that ergot alkaloids sensitized the pituitary-adrenal axis for cortisol secretion. The kinetics of the cortisol response to LPS here were similar to previous reports in cattle (Giri et al. 1990, Elsasser et al. 1994) and sheep (Coleman et al. 1993, Briard et al. 1998). The general mechanism for the cortisol response to LPS appears to be both increased adrenocorticotropin (ACTH) and hypothalamic corticotropin-releasing hormone (Dadoun et al. 1998). The mechanism for the increased cortisol response to LPS in the E + group may well have been secondary to increased TNF- $\alpha$ considering that 
TNF- $\alpha$ is capable of increasing ACTH secretion (Sharp et al. 1989). Increased cortisol is associated with progressive muscle protein loss (Kaplan 1988). Together, the increased TNF- $\alpha$ and cortisol observed in the $\mathrm{E}+$ group indicate that exposure of animals to both $\mathrm{E}+$ fescue and infectious agents would result in decreased weight gains and muscle mass.

The lack of treatment effect on serum GH before and after LPS challenge indicates that grazing $\mathrm{E}+$ forage did not affect pituitary $\mathrm{GH}$ secretion and the observed increases in both $\mathrm{E}+$ and $\mathrm{E}-$ groups at particular timepoints may be due to normal GH pulsatility. It has been previously reported that steers grazing $\mathrm{E}+$ fescue had elevated basal but not thyrotropin-stimulated serum $\mathrm{GH}$ (Thompson et al. 1987). Plasma GH was also elevated in steers administered ergotamine intravenously (Browning et al. 1997). Somewhat in contrast, serum GH was not affected by $\mathrm{E}+$ fescue consumption in steers (Lipham et al. 1989). The effects of LPS on GH secretion are minor. Previously, LPS challenge resulted in decreased plasma GH in cattle (Kenison et al. 1991), but in increased circulating GH in sheep (Coleman et al. 1993, Briard et al. 1998). It is expected that the lower dose of LPS used in the present experiment may have been insufficient to modulate GH secretion, but more frequent blood sampling regimen may be necessary to confirm that. Overall, circulating $\mathrm{GH}$ appears to be less sensitive to LPS challenge compared with TNF- $\alpha$ and cortisol.

In contrast to the lack of effect of $\mathrm{E}+$ fescue consumption and LPS upon GH values, basal serum IGF-I values were reduced in the $\mathrm{E}+$ group. The consistently reduced serum IGF-I in E + agrees with Hazlett et al. (1998) where serum IGF-I was reduced in heifers on $\mathrm{E}+$ fescue compared with controls fed oats. Diet composition and intake modulated circulating IGF-I concentrations in steers (Elsasser et al. 1989). Undernutrition not only leads to decreased circulating IGF-I but also to uncoupling of the IGF-I regulation by GH. IGF-I is synthesized predominantly in the liver (Hossner et al. 1997) and perhaps the apparent uncoupling of IGF-I from GH here is a function of decreased hepatic function. Hepatic function appears compromised in cattle grazing $\mathrm{E}+$ fescue as evidenced by a reduction in circulating concentration of several hepatic enzymes (Oliver 1997). Because IGF-I is anabolic (Hossner et al. 1997), the decreased IGF-I values in the E+ group appear to be contributory to the decreased growth observed in fescue toxicosis (Thompson \& Suedemann 1993). Intake in the present study was not measured, but body weights clearly reflect depressed average daily gain and, perhaps, intake. A decreased intake would explain both decreased IGF-I and lack of effect on GH upon IGF-I secretion. Moreover, undernutrition can lead to a reduction in IGF-I but an increase in circulating GH due to the loss of negative feedback from IGF-I (Vance et al. 1992). Administration of LPS decreased plasma IGF-I in cattle and the decrease was not dependent on feed intake (Elsasser et al. 1995a). Reduced basal IGF-I values and the further reduction in serum IGF-I in the present experiment in response to LPS suggest that animals grazing E + fescue and exposed to pathogens would have a greater decrease in growth rates compared with animals independently exposed to only $\mathrm{E}+$ fescue or pathogens.

The decreased serum glucose in the $\mathrm{E}+$ group prior to LPS compared with $\mathrm{E}-$ differs from other reports. J W Oliver, R D Linnabary, J R Strickland, A E Schultze, J C Waller, H A Fribourg, L K Abney, E M Bailey \& M A Barnhill (personal communication) observed increased serum glucose in steers grazing $\mathrm{E}+$ fescue, whereas Lipham et al. (1989) found no difference in a similar experiment. A biphasic circulating glucose response to LPS in cattle has been reported with an initial hyperglycemia followed by a sustained hypoglycemia (Elsasser et al. 1996). The hyperglycemic phase may not be observed at low LPS doses (Giri et al. 1990). The hypoglycemic phase following LPS is considered detrimental (Elsasser et al. 1996) because it has considerable duration. LPS-induced hypoglycemia is a function of increased glucose utilization, increased glucose oxidation, and decreased gluconeogenesis (Johnson et al. 1997). Because there was no difference in the magnitude of the decrease in serum glucose following LPS in both the E + and E - groups, it appears as though the hypoglycemic effect was LPS driven. Moreover, the prevalence of hypoglycemia in spite of a substantial increase in serum cortisol further supports the notion that serum glucose control was a function of LPS. The fact that serum cortisol was elevated prior to an appreciable decrease in serum glucose indicates also that the cortisol response was not mediated by the decrease in serum glucose.

The increased SUN response to LPS as measured by the AUC response in the $\mathrm{E}+$ group compared with $\mathrm{E}-$ indicates that increased nitrogen metabolism occurred as a function of grazing $\mathrm{E}+$ fescue. Circulating urea nitrogen in steers has either been unaltered following $\mathrm{E}+$ fescue consumption (Lipham et al. 1989) or increased (Oliver 1997), possibly due to mild dehydration. The increased circulating urea nitrogen after LPS is a function of decreased protein synthesis, lowered capacity for nitrogen retention, and increased mobilization of skeletal muscle amino acids (Zamir et al. 1992, Elsasser et al. 1996, Webel et al. 1997). Temporally, urea nitrogen increased at 8 and $12 \mathrm{~h}$ post LPS treatment in pigs (Webel et al. 1997), whereas in cattle the greatest increase was from 6 to $12 \mathrm{~h}$ post LPS treatment (Elsasser et al. 1996). The increased AUC response for SUN by E + here may be an integrated response to the decreased IGF-I and the increased serum cortisol and TNF- $\alpha$ which all favor protein degradation with perhaps a direct effect of LPS as well. Therefore, again the metabolic response to LPS in the E+ group is balanced towards catabolism such that contact with pathogens or perhaps another inflammatory agent would lead to increased tissue loss. 
In summary, the hypothesis that chronic exposure to ergot alkaloids in cattle grazing $\mathrm{E}+$ tall fescue results in a greater host response to LPS is supported. Therefore, chronic exposure to ergot alkaloids in E+ fescue sensitizes the animal to inflammatory agents such as LPS. Roth et al. (1997) suggest that concomitant exposure to LPS and certain toxicants increases the toxicity of the toxic agent. In the case here, chronic exposure to ergot alkaloids results in a greater host response to LPS that potentially would increase susceptibility to disease or another stress.

\section{Acknowledgements}

This research was funded by Section 1433 Animal Health and Disease Research Funds, USDA. The authors express appreciation to $\mathrm{Mr} \mathrm{D}$ Hildreth for assistance in data collection, and to USDA/ARS, Growth Biology Laboratory, Beltsville, MD, USA and USDA/ARS Animal Physiology Laboratory, Athens, GA, USA for providing their facilities and expertise for most of the hormonal and blood chemistry assays.

\section{References}

Aldrich CG, Paterson JA, Tate JL \& Kerley MS 1993 The effects of endophyte-infected tall fescue consumption on diet utilization and thermal regulation in cattle. Journal of Animal Science 71 164-170.

Briard N, Gulliame V, Franchebois C, Rico-Gomez M, Sauze N, Oliver C \& Dutour A 1998 Endotoxin injection increases growth hormone and somatostatin secretion in sheep. Endocrinology 139 2662-2669.

Browning R Jr, Thompson FN, Sartin JL \& Leite-Browning ML 1997 Plasma concentrations of prolactin, growth hormone, and luteinizing hormone in steers administered ergotamine or ergonovine. Journal of Animal Science 75 796-802.

Browning R Jr, Leite-Browning ML, Smith HM \& Wakefield T Jr 1998 Effect of ergotamine and ergonovine on plasma concentrations of thyroid hormones and cortisol in cattle. Journal of Animal Science 76 1644-1650.

Cheryk LA, Hooper-McGrevy KE \& Gentry PA 1998 Alterations of bovine platelet function and acute phase proteins induced by Pasteurella haemolytica A1. Canadian Journal of Veterinary Research 62 $1-8$.

Coleman ES, Elsasser TH, Kemppaimen RJ, Coleman DA \& Sartin JL 1993 Effect of endotoxin on pituitary hormone secretion in sheep. Neuroendocrinology 58 111-122.

Dadoun F, Guillaume V, Sauze N, Farisse J, Velut J, Orsoni J, Gaillard R \& Oliver C 1998 Effect of endotoxin on the hypothalamic-pituitary-adrenal axis in sheep. European Journal of Endocrinology 138 193-197.

Elsasser TH, Hammond AC, Rumsey TS \& Fayer R 1986 Perturbed metabolism and hormonal profiles in steers infected with Sarcocystis cruzi. Domestic Animal Endocrinology 3 277-287.

Elsasser TH, Rumsey TS, Hammond AC \& Fayer R 1988 Influence of parasitism on plasma concentrations of growth hormone, somatomedin-C and somatomedin-binding proteins in calves. Journal of Endocrinology 116 191-200.

Elsasser TH, Rumsey TS \& Hammond AC 1989 Influence of diet on basal and growth hormone-stimulated plasma concentrations of IGF-1 in beef cattle. Journal of Animal Science 67 128-141.
Elsasser TH, Fayer R, Rumsey TS \& Hartnell GF 1994 Recombinant bovine somatotropin blunts plasma tumor necrosis factor- $\alpha$, cortisol, and thromboxane- $\mathrm{B}_{2}$ responses to endotoxin in vivo. Endocrinology 134 1082-1088.

Elsasser TH, Caprena TJ \& Rumsey TS 1995a Endotoxin administration decreases plasma insulin like growth factor (IGF)-I and IGF-binding protein-2 in Angus $\times$ Hereford steers independent of changes in nutritional intake. Journal of Endocrinology 144 109-117.

Elsasser TH, Steele NC \& Fayer R $1995 b$ Cytokines, stress, and growth modulation. In Cytokines in Animal Health and Disease, pp 261-290. Eds MJ Myers \& MP Murtaugh. New York: Marcel Dekker.

Elsasser TH, Richards M, Collier R \& Hartnell GF 1996 Physiological responses to repeated endotoxin challenge are selectively affected by recombinant bovine somatotropin administration to calves. Domestic Animal Endocrinology 13 91-103.

Giri SN, Emau P, Cullor JS, Stabenfeld GH, Bruss ML, Bondurant RH \& Osburn BI 1990 Effect of endotoxin infusion on circulating levels of eicosanoids, progesterone, cortisol, glucose and lactic acid, and abortion in pregnant cows. Veterinary Microbiology 21 211-231.

Glenn AE, Bacon CW, Price R \& Hanlin RT 1996 Molecular phylogeny of Acremonium and its taxonomic implications. Mycologia 88 369-383.

Godson DL, Baca-Estrada ME, Van Kessel AG, Hughes HP, Morsy MA, Van Donkersgoed J, Harand RJ, Shuster DE, Daley MJ \& Babiuk LA 1995 Regulation of bovine acute phase responses by recombinant interleukin-1 $\beta$. Canadian Journal of Veterinary Research 59 249-255.

Hazlett WD, Lester TL \& Rorie RW 1998 Influence of endophyteinfected fescue on serum and intra-uterine insulin growth factor I and II in beef heifers. Journal of Animal Science 76 (Suppl 1) 230.

Hill NS \& Agee CS 1994 Detection of ergoline alkaloids in endophyte-infected tall fescue by immunoassay. Crop Science $\mathbf{3 4}$ $530-534$.

Hill NS, Thompson FN, Dawe DL \& Stuedemann JA 1994 Antibody binding of circulating ergot alkaloids in cattle grazing tall fescue. American Journal of Veterinary Research 55 419-424.

Hossner KL, McCusker RH \& Dodson MV 1997 Insulin-like growth factors and their binding proteins in domestic animals. Animal Science 64 1-15.

Johnson RW, Arkins S, Dantzer R \& Kelley KW 1997 Hormones, lymphohemopoetic cytokines and the neuroimmune axis. Comparative Biochemistry and Physiology 116A 183-201.

Kahl S, Elssaser TH \& Blum JW 1997 Nutritional regulation of plasma tumor necrosis factor- $\alpha$ and plasma urinary nitrite/nitrate responses to endotoxin in cattle. Proceedings of the Society for Experimental Biology and Medicine 215 370-376.

Kaplan NM 1988 The adrenal glands. In Textbook of Endocrine Physiology, pp 245-273. Eds JE Grifith \& SR Ojeda. New York: Oxford University Press.

Kenison DC, Elsasser TH \& Fayer R 1990 Radioimmunoassay for bovine tumor necrosis factor: concentrations and circulating molecular forms in bovine plasma. Journal of Immunoassay $\mathbf{1 1}$ 177-198.

Kenison DC, Elsasser TH \& Fayer R 1991 Tumor necrosis factor as a potential mediator of acute metabolic and hormonal responses to endotoxemia in calves. American Journal of Veterinary Research $\mathbf{5 2}$ $1320-1326$.

Lipham LB, Thompson FN, Stuedemann JA \& Sartin JL 1989 Effects of metoclopramide on steers grazing endophyte-infected fescue. Journal of Animal Science 67 1090-1097.

Mizinga KM, Thompson FN, Stuedemann JA \& Kiser TE 1992 Effects of feeding diets containing endophyte-infected fescue seed on luteinizing hormone secretion in postpartum beef cows and in cycling heifers and cows. Journal of Animal Science 70 3483-3489. 
Oliver JW 1997 Physiological manifestations of endophyte toxicoses in ruminant and laboratory species. In Neothyphodium/grass interactions, pp 311-347. Eds CW Bacon \& NS Hill. New York: Plenum Press.

Porter JK 1995 Analysis of endophyte toxins: Fescue and other grasses toxic to livestock. Journal of Animal Science 73 871-878.

Purdy CW, Cole NA \& Stuedemann JA 1989 The effect of fescue toxicosis on classical complement in yearling feeder cattle. Journal of Veterinary Diagnostic Investigation 188.

Roth RA, Harkema JR, Pestuka JP \& Ganey PE 1997 Is exposure to bacterial endotoxin a determinant of susceptibility to intoxication from xenobiotic agents? Toxicology and Applied Pharmacology 147 300-311.

Sharp BM, Matta SG, Peterson PK, Newton R, Chao C \& McAllen K 1989 Tumor necrosis factor-alpha is a potent ACTH secretagogue: comparison with interleukin-1 $\beta$. Endocrinology 125 2800-2805.

Spurlock ME 1997 Regulation of metabolism and growth during immune challenge: an overview of cytokine function. Journal of Animal Science 75 1773-1783.

Thompson FN \& Stuedemann JA 1993 Pathophysiology of fescue toxicosis. Agriculture, Ecosystems and Environment 44 263-281.

Thompson FN, Stuedemann JA, Sartin JL, Belesky DP \& Devine OJ 1987 Selected hormonal changes with summer fescue toxicosis. Journal of Animal Science 65 727-733.
Vaisman N, Schattner A \& Hahn T 1989 Tumor necrosis factor production during starvation. American Journal of Medicine $\mathbf{8 7}$ 115-122.

Vance ML, Hartman ML \& Thorner MO 1992 Growth hormone and nutrition. Hormonal Research 38 85-88.

Webel DM, Finck BN, Baker DH \& Johnson RW 1997 Time course of increased plasma cytokines, cortisol, and urea nitrogen in pigs following intraperitoneal injection of lipopolysaccharide. Journal of Animal Science 75 1514-1520.

Young CR, Eckersall PD, Saini PK \& Stanker LH 1995 Validation of immunoassays for bovine haptoglobin. Veterinary Immunology and Immunopathology 49 1-13.

Young CR, Wittum TE, Stanker LH, Perino LJ, Griffin DD \& Littledike ET 1996 Serum haptoglobin concentrations in a population of feedlot cattle. American Journal of Veterinary Research $\mathbf{5 7}$ 138-141.

Zamir O, Hasselgren P, Kunkel SL, Frederick J, Higashiguchi T \& Fischer JE 1992 Evidence that tumor necrosis factor participates in the regulation of muscle proteolysis during sepsis. Archives of Surgery 127 170-174.

Received 9 March 1999

Accepted 8 June 1999 